\title{
Editorial: The Imperfection of Politics
}

In an earlier age there was much discussion of a so-called 'paradox of democracy'. The point seemed to be about what would happen if a democratic society voted democratically to abolish its democratic procedures and to move to a dictatorship. Would that be democratic or not?

At least in the West there seems little prospect at the moment of that paradox being actualized, real enough as it may have been in the 1930s. But what we have had recently in Britain and the USA are two elections widely held to be unsatisfactory, though for rather different reasons. One was, in the jargon 'too close to call' and the result still disputed, while the other was so one sided as to be no contest at all.

But underlying the different ostensible causes for dissatisfaction is a common theme: the large number of voters who simply did not vote. In Britain the 'apathy party' would have swept the board, had there, paradoxically, been such a thing. Low voter turn out has been an American complaint for decades.

Yet there may be another paradox, pragmatically speaking. In Britain, in so far as there was an issue it was about 'public services', that is state provision of items like health, education and transport. People showed very decisively in public opinion polls that they expected the state, that is politicians, to run these matters. At the same time, when it came to the election itself $40 \%$ or more could not be bothered to vote for those whom they expect to run large swathes of their lives. Is it that they both believe and do not believe in the importance of politics and the role of politicians? 